(donkey), strength and arrogance, justice, the more powerful of law sensation (lion).

Conclusions. Summarizing our thoughts above, it would be emphasized that justice is a law sensation that dictates a person to strive for what belongs to $\mathrm{him} /$ her. But to grasp justice as an internal aspect - it is necessary that a person, first of all, strong and powerful, the justice sensation does not develop to the apogee. On the contrary - it translated from the law sensation to duty, not only to take, but to give. In the mind there must be a need to seek all means to refuse at least some of the rights of their own pleasure for the common good. Justice and understanding between people are possible not when a strong person, nation or state enforces a coercively different recognition of their rights that they may find unfair and incomprehensible, and when they develop a sensation of solidarity that transforms a sensation of justice, make it more distinct not for their own rights, but for improving the situation of others.

Thus, the ideals of justice are truly revealed on the basis of the high beginnings of humanity, truthfulness, the desire for harmony of conscience with the laws of God: do not jealous, do not be envy, drive away arrogance - a close friend of pride.

\section{REFERENCES}

1. Hegel, G. (1976). The spirit of Christianity and its fate. Philosophical religions in Vol. I - II, V I. K.: Mysl, pp. 101-102.

2. Legal Encyclopedia (1998). Legal Encyclopedia in 6 volumes. Vol. V. Kyiv: “Ukr. Encyc”, p. 736.

3. Marcus Tullius Cicero (2018). Available at: https:// www.britanica.com/biography/Cicero

4. Plato's tripartite theory of soul (2018). Available at: https://en.wikipedia.org/wiki/Plato\%27s_tripartite _theory_of_soul

5. Political Theory - Confucius on the proper role of government (2018). Available at: http://selfdeprecate.com/ politics-articles/confucius-proper-role-government/

6. Vasyanovych, G. V. (2005). Pedagogical Ethics: teaching method. Lviv: "Norma", $344 \mathrm{p}$.

7. Zvarych, I. M. (2015). Theoretical and Methodological Basic of Assessment the Lecturers' Pedagogic Activities at the USA's Higher Education Institutions. Kyiv: Fenix, p. 144.

Стаття надійшла до редакції 04.09.2018

УДК 378.147:61 - 057.86

DOI:

Ірина Кишакевич, доктор медичних наук, професор кафедри акушерства і гінекології післядипломної освіти Івано-Франківського національного медичного університету

\title{
ПРО ДЕЯКІ ПЕДАГОГІЧНІ АСПЕКТИ ПРОФЕСІЙНОЇ ДІЯЛЬНОСТІ МЕДИЧНИХ ПРАЦІВНИКІВ
}

У статті описано елементи структури педагогічної компетентності, з якими найчастіше зустрічаються у практиці медичні працівники. Цими елементами повинен оволодівати майбутній медик у прочесі підготовки у медичних навчальних закладах. Автор детально висвітлює врахування психологопедагогічних вимог медичними працівниками при підготовці і проведенні санітарно-просвітницької діяльності, наданні медико-соиіальної допомоги окремим категоріям населення.

Ключові слова: педагогічна компетентність; лікувально-профілактична діяльність; скрайбінг; психологічний портрет особистості.

Jim. 7.

Iryna Kyshakevych, Doctor of Sciences (Medicine), Professor of the Obstetrics and Gynecology Postgraduate Education Department Ivano-Frankivsk National Medical University

\section{SOME PEDAGOGICALASPECTS OF PROFESSIONAL ACTIVITIES OF MEDICAL WORKERS}

Among the primary medical sanitary help there are such functions as: to carry out the sanitary educational work, to organize the medical social help for the elderly people, disableds, and chronically ill together with the social protection organizations. The medical workers should know some pedagogical competence of the professional activity. The medical institutions should teach this pedagogical competence.

The article shows how to take into account some requirements of general pedagogy before preparing for the lectures and holding lectures with the listeners. Such questions as motivating the listeners at the beginning of the lesson, using new technologies of scrabble are shown in details.

A medical worker should be aware of indicator and disturbance of mental health, determine the psychological 


\section{ПРО ДЕЯКІПЕДАГОГЧНІ АСПЕКТИПРОФЕСІЙНОЇ ДІЯЛЬНОСТІМЕДИЧНИХ ПРАЦІВНИКІВ}

portrait of the patient and consider them while communicate or treat. The author describes the formation of mental component of the professional competence of the medical worker.

The author pays attention to the pedagogical competence of the medical workers while complying the laws of Ukraine "About the protection of childhood", "About the support of social formation and development of youth", "About state social assistance to low-income families" etc.

Keywords: the pedagogical competence; the medical and preventive activities; scribing; the psychological portrait of the person.

П остановка проблеми. Всесвітня організація охорони здоров'я прийняла для всіх країн визначення первинномедико-санітарної допомоги (ПМСД), перелічивши іï функції. Серед них є такі:

- проведення санітарно-просвітньої роботи;

- надання консультативної допомоги сім'ям 3 питань харчування і виховання дітей, підготовки їх до дитячих дошкільних закладів і шкіл, планування сім'ї;

- організація разом 3 органами соціального захисту і служби милосердя медико-соціальної допомоги особам похилого віку, інвалідам, хронічно хворим.

Медичні працівники повинні не тільки надавати медичну допомогу людям, але й формувати їх бережне ставлення до свого здоров'я, всіляко пропагувати здоровий спосіб життя - основний фактор збереження стану здоров'я людини. Звідси випливає, що медичний працівник повинен володіти не тільки знанням спеціальних медичних дисциплін і медичними навичками та вміннями, але й мати певну педагогічну компетентність. Лікарі сімейної медицини повинні знати, крім того, ще й основи соціальної роботи.

У роботах [5;7] досліджуються питання поліпшення стану здоров'я та санітарної освіти населення Західної Європи. Про вимоги до педагогічної компетентності медичних працівників пишеться у [2]. Професійній компетентностіприсвячені праці Н. Бібік,Р. Гуревича, О. Дубасенюк, І. Зязюна, Н. Ничкало, О. Овчарук, В. Радкевич, С. Сисоєвої, В. Ягупова та багатьох інших. Узагальнення їхніх поглядів дозволяє стверджувати, що компетентність - усталена здатність обізнаної в певній галузі людини, що характеризується глибоким розумінням змісту й сутності виконуваних завдань і вирішуваних проблем. Аналіз поняття педагогічної компетентності сімейних лікарів 3 урахуванням особливостей їхньої професійної діяльності дано $\mathrm{y}[4]$.

Мета статті - виділити у структурі педагогічної компетентності ті елементи, які найчастіше застосовуються медичними працівниками, і на яких слід зосередити увагу у підготовці медичних працівників узакладах вищої освіти.
Виклад основного матеріалу. I. Зязюн вважає, що професійно-педагогічна компетентність $\epsilon$ цілісноюпрофесійно-особистісною характеристикою, що відображає готовність і здатність людини професійно виконувати педагогічні функції згідно 3 прийнятими в суспільстві нормами і стандартами $[1,6]$. Вона дозволяе ефективно виконувати навчально-виховну діяльність, цілеспрямовано організовувати педагогічну взаємодію, а також передбачає саморозвиток, самовиховання, вдосконалення особистості та майстерності викладача.

Лікувально-профілактична діяльність передбачає лікарську рефлексію, тобто обов'язкове усвідомлення іiі сенсу, змісту, засобів і способів виконання, а також спирається на систему цінностей особистості; педагогічна діяльність медичного працівника спрямовується на проектування освітнього процесу і передбачає педагогічну рефлексію, тобто обов'язкове усвідомлення всіх параметрів і чинників успішності виконання цієї діяльності.

Одним із важливих видів освітньої діяльності медичного працівника $\epsilon$ проведення лекційних, практичних занять у рамках санітарнопросвітницької роботи. Коротко опишемо підготовку і проведення таких занять.

Лише вмотивований викладач структуровано готується до занять, переконливо доносить інформацію i, найголовніше - може вмотивувати аудиторію. Лише вмотивована аудиторія готова слухати і сприймати інформацію та сумлінно відпрацьовувати практичні завдання до набугтя необхідної навички. Відповідно, невмотивованому викладачу не слід й виходити до аудиторії та витрачати іï час.

Педагогіка вимагає чіткого визначення цілей навчання і розуміння потреб аудиторії. Викладач має врахувати: цілі, потреби, очікування, мотивацію, попередні знання, тип особистості, стиль сприйняття інформації студентами.

Bсі ці пункти мають бути визначеними ще під час підготовки до заняття і основною задачею викладача протягом заняття буде підтримування мотиваиіiі.

Щоб “вписатися” у цю модель, викладачу необхідна всебічна підготовка до проведення заняття. Будь-яке заняття $\epsilon$ процесом комунікації 


\section{ПРО ДЕЯКІПЕДАГОПІЧНІ АСПЕКТИПРОФЕСІЙНОЇ ДІЯЛЬНОСТІМЕДИЧНИХ ПРАЦІВНИКІВ}

між викладачем і аудиторією. Комунікація за американським психологом Альбертом Мерабіаном буває вербальною (що сказано?), вокальною (як сказано?) і візуальною (що спостерігається?). Якщо вербальна складова комунікації полягає у змістовому наповненні, то вокальна - в інтонації, темпі і гучності мовлення, а візуальна визначається мімікою, жестами, зовнішнім виглядом викладача. Не варто недооцінювати вокальну і візуальну складову комунікації. Кожен викладач повинен постійно удосконалювати свій голос, поведінку при викладанні, а це вимагає самоконтролю і практики.

Повноцінне заняття має складатися із трьох частин: вступу, основної частини, висновку. Зазвичай, заняття порівнюють або із будинком, де вступ $є$ фундаментом, основна частина стінами, а висновок - дахом. Досвід показує, що нехтування однією із цих частин (непереконливий вступ чи змазаний висновок) неодмінно веде до зниження ефективності заняття.

Вступ повинен привернути увагу і викликати інтерес аудиторії. Для того, щоб вступ був ефективним, він повинен займати не більше,ніж 3 - 5 хвилин і бути стислим. Зі вступу слухачі мають зрозуміти:

- Що вони будуть вивчати? (цілі)

- Чому для них важливо це вміти? (мотивація)

- Як вони будуть цього навчатися? (план)

Для мотивації аудиторії викладач може описати проблему, вирішення якої аудиторія повинна знайти до кінця заняття, розповісти анекдот або повчальну історію, які доведуть важливість цієї теми, запитати у аудиторії іiі думку або особистий досвід. (Найбільш мотивованими будуть ті, кому дадуть можливість висловити свою точку зору).

Під час викладу основної частини бажано використовувати новітню техніку презентації скрайбінг.

Скрайбінг - процес візуалізації складного змісту просто й доступно, під час якого замальовка образів відбувається прямо під час передачі інформації.

Особливість скрайбінгу полягає в тому, що одночасно залучаються різні органи чуттів: слух та зір, а також уява людини, що сприяє кращому розумінню та запам'ятовуванню. Саме ці особливості роблять скрайбінг одним із методів сучасних технологій, який допомагає доступно та легко пояснювати складний матеріал. Варто відзначити його доступність, адже використовувати цю техніку може кожна людина у своїх щоденних справах.

Отже, скрайбінг (від англійського scribe - накидати ескізи або малюнки) - новітня техніка презентації, у якій мова оратора ілюструється “на льоту” малюнками на білій дошці (або аркуші паперу), яка була винайдена британським художником Ендрю Парком для Британської асоціації з поширення наукових знань.

Під час скрайбінгу виходить ніби “ефект паралельного проходження”, коли ми й чуємо, й бачимо приблизно одне й те ж, при цьому графічний ряд фіксується на ключових моментах аудіоряду. Наразі скрайбінг - інноваційна технологія, за допомогою якої можна привернути увагу слухачів, забезпечити їх додатковою інформацією та виокремити головні моменти доповіді.

Є два основних види скрайбінгу: фасилітація та відеоскрайбінг. Скрайбінг-фасилітація (від англійського facilitate - допомагати, полегшувати, сприяти) - це переклад інформації зі словесної форми у візуальну та фіксування їі у режимі реального часу. Робота викладача на занятті під час пояснення нового матеріалуз крейдою в руках - приклад скрайбінгу-фасилітації. Переваги відеоскрайбінгу полягають у тому, що відеоролик можна використовувати безліч разів, цей вид діяльності викликає у виконавців особливу зацікавленість.

Можна також виділити декілька найпоширеніших видів відеоскрайбінгу мальований скрайбінг, аплікаційний скрайбінг та онлайн-скрайбінг.

Мальований скрайбінг є класичним видом скрайбінгу. Художник (скрайбер) зображує в кадрі картинки, піктограми, схеми, діаграми, записує ключові слова. Це відбувається паралельно 3 текстом, що звучить за кадром.

Аплікаційний скрайбінг - на довільний фон у кадрі накладаються чи наклеюються готові зображення, які відповідають тексту, що озвучується. Магнітний скрайбінг є різновидом аплікаційного, єдина відмінність - готові зображення кріпляться магнітами на презентаційну магнітну дошку.

Онлайн-скрайбінг - при створенні цього виду скрайбінгу використовуються спеціальні програми й онлайн-сервіси, наприклад PowToon, VideoScribe та інші. 3 їх допомогою відео можна створювати за готовими шаблонами, однак безкоштовні можливості зазначених сервісів обмежені.

У сучасному світі скрайбінг успішно використовують викладачі навчальних закладів для створення зрозумілих та легких для запам'ятовування схем; для передачі своїх думок колегам у ході презентацій, круглих столів, конференцій тощо. 
У висновку не рекомендують давати нової інформації (вся вона має бути розглянута і відпрацьована у основній частині), а тільки коротко переглянути вивчене. Під час підбивання підсумків доречно вказати, як вивчений матеріал вписується у загальну картину курсу/предмета. Крім того, висновок дає можливість аудиторії поставити запитання викладачу щодо матеріалу заняття, а також і викладачу поставити запитання аудиторії, щоб перевірити, наскільки був сприйнятий і засвоєний матеріал Запитання є дуже важливою складовою, бо вони створюють зворотній зв'язок із аудиторією, але вони ж можуть стати проблемою і зруйнувати всю структуру заняття. Тому під час заняття відповідайте лише на ті питання, що стосуються теми, а решту залишайте на потім (на кінець заняття або на перерву). Даючи відповідь на запитання, посилайтеся на основну частину заняття - це посилює і роз'яснює сказане.

Професійна компетентність медичного працівника, крім суто медичного, охоплює і психолого-педагогічний компонент. Це означає, що для забезпечення ефективності лікувальнопрофілактичного процесу він має знати анатомофізіологічні і психологічні особливості людей різних вікових груп, специфіку розвитку дітей i підлітків.

Зупинимося коротко на показниках i порушеннях психічного і особистісного розвитку. Як вважає М. Савчин, Л. Василенко [3], “психічний і особистісний розвиток має певні показники. Його метою є психічно здорова особистість. Він не завжди відбувається оптимально, нерідко супроводжується суттєвими порушеннями". Основними показниками психічного і особистісного розвитку, за М. Савчиним, Л. Василенко [3], є такі:

- розвиток свідомості особистості;

- розвиток психічної структури діяльності особистості;

- розвиток суб'єктності дитини;

- розвиток духовності особистості;

- довільність у поведінці та в організації психічних процесів особистості.

А психологічний портрет зрілої особистості визначають:

- відчуття великої потреби в духовному (духовних переживаннях, духовному зростанні, духовних діях);

- відкритість власним переживанням;

- усвідомлення відповідальності за своє життя, свої життєві вибори, конкретну поведінку;

- різнобічний і постійний розвиток власної особистості;
- висока самосвідомість, глибоке і всебічне самопізнання;

- демократичний характер;

- висока креативність (здатність до творчості у всіх сферах життя);

- відсутність нерозумних і суперечливих думок, ілюзій, деструктивних прагнень і намірів, здатність надати собі у стресовій ситуації психологічну допомогу;

- спонтанність, невимушеність, простота, природність, прагнення до справжності (автентичності), вишуканість;

- уміння жити своїм розумом і чужими переживаннями;

- конструктивність у всіх сферах життя (прагнення досягати конкретних результатів у діяльності, в житті, праця на віддалений результат.

М. Савчин, Л. Василенко [3] визначають такі основні порушення психічного розвитку:

- психічний та особистісний недорозвиток;

- затримання психічного та особистісного розвитку;

- пошкоджений психічний та особистісний розвиток;

- спотворений психічний та особистісний розвиток;

- дисгармонійний психічний та особистісний розвиток.

Ці типи порушень повинні враховувати батьки, педагоги, психологи, медичні працівники упроцесі виховання, навчання та лікування дітей, корекційної роботи з ними.

Особливу увагу медичний працівник повинен звернути на ставлення родини до дитини-інваліда. Це ставлення може бути різним: конструктивним, деструктивним, акцентуйованим.

При конструктивному ставленні родина не заглиблюється в переживання, а вроджену або набуту ваду не роглядає як обмеження на шляху особистісного розвитку дитини. Родина постійно шукає шляхи компенсації наявних порушень, терпеливо розвиває здібності дитини і підтримує їі.

Деструктивне ставлення до дитини проявляється в ігноруванні їі патології, інколи навіть у перешкоджанні іï оздоровлення. Деструктивне ставлення до дитини може виражатися також у негативізмі, тобто негативному ставленні до неї, яке може носити як явний, так і прихований характер. При явному негативному ставленні батьки, члени родини бачать у дитині-інваліді причини всіх своїх негараздів, що призводить до жорстокого поводження 3 нею. Приховане деструктивне ставлення проявляється в емоційному відчуженні дитини-інваліда. 


\section{ПРО ДЕЯКІПЕДАГОПІЧН АСПЕКТИПРОФЕСІЙНОӤ ДІЯЛЬНОСТІ МЕДИЧНИХПРАЦІВНИКІВ}

Якщо спосіб життя родини цілковито зорієнтований на хворобу дитини і залежить від неї, то кажуть, що має місце акцентуйоване ставлення родини до дитини-інваліда. Воно проявляється у різних невротичних проявах у членів родини, тривожності, низькій самооцінці, почутті провини. Це згодом передається і дитині.

Зупинимося коротко на участі медичного працівника в організації разом 3 органами соціального захисту і служби милосердя медикосоціальної допомоги особам похилого віку, інвалідам, хронічно хворим. Для цього медичному працівникові потрібно знати про соціальну роботу у нашій державі, суб' єкти іiі організації, правове забезпечення.

Соціальна робота - унікальний вид професійної діяльності зі створення соціальних умов для поліпшення умов життя окремої особистості, підвищення добробугу народу. Як вид професійної діяльності соціальна робота сформувалася на базі системи соціального захисту населення, освіти, охорони здоров'я, соціальних служб для молоді, спеціалізованих закладів і установ. Складні соціально-економічні умови життя зумовили необхідність розробки сучасних наукових i прикладних підходів до соціального впливу на індивіда та його оточення. 3 одного боку фінансова підтримка держави, адаптація суспільства до потреб особистості, з іншого створення відповідних соціальних умов для самоудосконалення і самореалізації особистості у напрямі оволодіння нею економічної спроможності.

Соціальний захист інвалідів з боку держави регламентується Законом України "Про основи соціальної захищеності інвалідів Україні” від 21.03.1991 р. і полягає у наданні грошової допомоги, засобів пересування, протезування, допомоги в орієнтації і сприйнятті інформації, пристосованого житла, у встановленні опіки або стороннього догляду, а також пристосуванні забудови населених пунктів, громадського транспорту, засобів комунікацій та зв'язку до особливостей інвалідів. Діяльність держави щодо інвалідів виявляється у створенні правових, економічних, політичних, соціально-побутових та соціально-психологічних умов для задоволення їх потреб у відновленні здоров'я, матеріальному забезпеченні, посильній трудовій та громадській діяльності.

Згідно із Законом України "Про сприяння соціальному становленню та розвитку молоді в Україні” від 05.02.1993 р. на обласному, міському та районномурівнях створюються соціальні служби для молоді. Основні завдання цих служб такі:
- реалізація державної молодіжної політики щодо соціального становлення та розвитку молоді; - інформаційна, правова психолого-педагогічна, медична та інші форми допомоги молоді;

- заходи щодо попередження й подолання негативних явищ у молодіжному середовищі;

- соціальна опіка окремої соціальної роботи 3 молоддю.

“Законодавство про державну соціальну допомогу складається з Закону України "Про прожитковий мінімум”, цього Закону, інших нормативно-правових актів, що регулюють правовідносини з надання державної соціальної допомоги". Розмір державної соціальної допомоги визначається як різниця між прожитковим

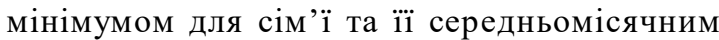
сукупним доходом, але не може бути більшим ніж 75 відсотків прожиткового мінімуму для сім’ї. До стабілізації економічного становища в Україні розмір державної соціальної допомоги визначається з урахуванням рівня забезпечення прожиткового мінімуму. Рівень забезпечення прожиткового мінімуму встановлюється, виходячи 3 реальних можливостей видаткової частини Державного бюджету України, і затверджується одночасно з прийняттям закону про Державний бюджет України на відповідний рік.

Закон України "Про межу малозабезпеченості" від 04.10.1994 p. встановлює величину середньодушового доходу, який забезпечує непрацездатному громадянинові споживання товарів та послуг на мінімальному рівні.

Закон України "Про охорону дитинства" від 26.04.2001p. 3 наступними змінами визначає охорону дитинства в Україні як стратегічний загальнонаціональний пріоритет і $з$ метою забезпечення реалізації прав дитини на життя, охорону здоров'я, освіту, соціальний захист та всебічний розвиток встановлює основні засади державної політики у цій сфері. У статті 4 цього Закону говориться:

“Система заходів щодо охорони дитинства в Україні включає:

- визначення основних правових, економічних, організаційних, культурних та соціальних засад щодо охорони дитинства, удосконалення законодавства про правовий і соціальний захист дітей, приведення його у відповідність 3 міжнародними правовими нормами у цій сфері;

- забезпечення належних умов для охорони здоров'я, навчання, виховання, фізичного, психічного, соціального, духовного та інтелектуального розвитку дітей, їх соціальнопсихологічної адаптації та активної 
життєдіяльності, зростання в сімейному оточенні в атмосфері миру, гідності, взаємоповаги, свободи та рівності;

- проведення державної політики, спрямованої на реалізацію цільових програм 3 охорони дитинства, надання дітям пільг, переваг та соціальних гарантій у процесі виховання, навчання, підготовки до трудової діяльності, заохочення наукових досліджень 3 актуальних проблем дитинства;

- встановлення відповідальності юридичних і фізичних осіб (посадових осіб і громадян) за порушення прав і законних інтересів дитини, заподіяння їй шкоди”.

Стаття 6 цього Закону утверджує права дитини на життя та охорону здоров'я. У ній записано:

"Кожна дитина має право на життя з моменту визначення іiі живонародженою та життєздатною за критеріями Всесвітньої організації охорони здоров'я.

Держава гарантує дитині право на охорону здоров'я, безоплатну кваліфіковану медичну допомогу в державних і комунальних закладах охорони здоров'я, сприяє створенню безпечних умов для життя і здорового розвитку дитини, раціонального харчування, формуванню навичок здорового способу життя.

3 цією метою держава вживає заходів щодо:

- зниження рівня смертності немовлят і дитячої смертності;

- забезпечення надання необхідної медичної допомоги всім дітям;

- боротьби з хворобами і недоїданням, у тому числі шляхом надання дітям доступу до достатньої кількості якісних харчових продуктів та чистої питної води;

- створення безпечних і здорових умов праці;

- надання матерям належних послуг з охорони здоров'я у допологовий і післяпологовий періоди;

- забезпечення всіх прошарків суспільства, зокрема батьків і дітей, інформацією щодо охорони здоров'я і здорового харчування дітей, переваг грудного вигодовування, гігієни, санітарних умов проживання дітей та запобігання нещасним випадкам;

- розвитку просвітницької роботи, послуг у галузі планування сім’ї та охорони репродуктивного здоров'я;

- пільгового забезпечення дітей ліками та харчуванням у порядку, встановленому законодавством".

Висновки і пропозиції. Такі складові педагогічної компетентності медичних працівників як:

- застосування новітніх педагогічних технологій у санітарно-просвітницькій роботі 3 населенням;

- знання і врахування у медичній практиці психології людей різних вікових груп, показників психічного і особистісного розвитку дитини, їх порушень;

- надання кваліфікованої медичної допомоги дітям, інвалідам, малозабезпеченим відповідно до чинного законодавства повинні зайняти відповідне місце у підготовці медичних працівників, зокрема лікарів сімейної медицини, у закладах вищої освіти.

\section{ЛІТЕРАТУРА}

1.Зязюн I. А. Педагогічна майстерність як технологія педагогічної дії / I. А. Зязюн// Теорія і практика підготовки майбутніх учителів до педагогічної дії: матеріали Всеукр. наук.-практ. конф. 3 міжнародною участю, 20 - 21 травня 2011 р., м. Житомир. - Житомир: ЖДУ імені Івана Франка, 2011. - С. 6-13.

2. Лаптиева Л.Н., Врубдевская Е.И. Педагогические аспекты профессиональной деятельности медицинских работников.// Веснік Мазирскага дзяржаўнага педагагічнага ўніверсітета імя І.П. Шамякіна. 2014.

3.Савчин М.В., Василенко Л.П. Вікова психологія. - Київ. - Академвидав. - 2005. - 360 с.

4. Стечак Г.М. Структура педагогічної компетентності сімейного лікаря. Режим доступу: ldubgd.edu.ua/sites/default/files/3_nauka/svr/04/ d_stechak.pdf

5. Adair, J. The action centred leader. The Industrial Society / J. Adair-- London, 1988.

6. Rowson, R. H. An introduction to ethics for nurses / R.H. Rowson.- Harrow, Scutari Press, 1990.

7. Salvage, J. Nursing in Action: Strengthening nursing and midwifery to support health for all $/$ J. Salvage. - Copenhagen, WHO Regional Office for Europe, 1993 (WHO Regional Publications, European Series, no. 48).

\section{REFERENCES}

1. Ziaziun, I. A. (2011). Pedahohichna maisternist yak tekhnolohiia pedahohichnoi dii [Pedagogical skill as a technology of pedagogical action]. Teoriia $i$ praktyka pidhotovky maibutnikh uchyteliv do pedahohichnoi dii: materialy Vseukr. nauk.-prakt. konf. z mizhnarodnoiu uchastiu, 20 - 21 travnia, $m$. Zhytomyr - Theory and practice of preparing the future teachers for the pedagogical Action: the materials of Ukrainian scientific and practical conference with international participation, May 20 - 21, Zhytomyr. Zhytomyr: ZhDU imeni Ivana Franka, pp. 6 - 13.[in Ukrainian]. 


\section{ВАЖНОСТЬ ИННОВАЦИЙ ДЛЯ БЕДНЫХ В УПРАВЛЕНИИ НА ПУТИ К ЭКОНОМИЧЕСКОМУ РАЗВИТИЮ РЫНКОВ КОТОРЫЕ РАЗВИВАЮТСЯ}

2. Laptieva, L.N. \& Vrubdevskaya, Ye.I. (2014). the pedagogical competence of the family doctor]. Pedagogicheskie aspekty professionalnoy deyatelnosti meditsinskikh rabotnikov [The pedagogical aspects of professional activity of medical workers]. Herald of the Mazirskiy Ivan Shamyakin State University. [in Russian].

3. Savchyn, M.V. \& Vasylenko, L.P. (2005). Vikova psykholohiia [Age Psychology]. Kyiv, Akademvydav, 360 p. [in Ukrainian].

4. Stechak, H. M. Struktura pedahohichnoi kompetentnosti simeinoho likaria [The structure of Available at: ldubgd.edu.ua/sites/default/files/ 3_nauka/svr/04/d_stechak.pdf. [in Ukrainian].

5. Adair, J. (1988).The action centred leader.The Industrial Society. London. [in English].

6. Rowson, R. H. (1990). An introduction to ethics for nurses. Harrow, Scutari Press. [in English].

7. Salvage, J. (1993). Nursing in Action: Strengthening nursing and midwiferyto supporthealth for all. Copenhagen, WHO Regional Office for Europe, (WHO Regional Publications, European Series, no. 48). [in English].

Стаття надійшла до редакції 17.09.2018

УДК 364.662:330.34.014-026.23

DOI:

Лукаш Маковский, доктор философии, экономический факультет Познанской Высшей банковой школы, г. Хожув Анджей Кокель, доктор философии, экономический факультет Познанской Высшей банковой школь, г. Щецин

\section{ВАЖНОСТЬ ИННОВАЦИЙ ДЛЯ БЕДНЫХ В УПРАВЛЕНИИ НА ПУТИ К ЭКОНОМИЧЕСКОМУ РАЗВИТИЮ РЫНКОВ КОТОРЫЕ РАЗВИВАЮТСЯ}

Цель статьи - анализ проблемь и определение инноваций для бедньх людей, а также процессов которые их сопровождают. Поиск ответа на эти вопросы исследования поможет получить информацию о сути инновации по проблемам глобализации, технологии производства и другим актуальным проблем ХХ века, особенно на рынках которые имеют наибольшее количество бедного населения. В этой статье исследуется, как многонациональные корпорации, которые занимаются своим бизнесом и направляют произведенные товары и услуги на рынок “ВоР market”. Акцентируется внимание на проблеме развития возможностей совместной разработки бизнес-концепций и моделей с привлечением бедного населения.

Ключевые слова: инновацчии для бедных людей; экономический рост; развивающиеся рынки; рынок ВоР; рынок сбыта; инновации.

Табл. 1. Лит. 20.

Lukash Makovskiy, Doctor of Philosophy, Faculty of Economics Poznan Higher Banking School, Chorzow Andzey Kokel, Doctor of Philosophy, Faculty of Economics Poznan Higher Banking School, Szczecin

\section{THE IMPORTANCE OF INNOVATIONS FOR THE POOR PEOPLE IN MANAGEMENT ON THE WAY OFTHE ECONOMIC DEVELOPMENT OF THE DEVELOPING MARKETS}

The purpose of the article is to analyze the problem and identify innovations for poor people, as well as the processes that accompany them. Finding the answer to these research questions will help to obtain the information about the essence of innovation on the problems of globalization, production technology and other pressing problems of the XXth century, especially in the markets that have the largest number of poor people. This article explores how multinational corporations run their businesses and direct manufactured goods and services to the "BoP market". The article focuses on the problem of developing the possibilities of joint working out of business-concepts and models with the involvement of the poor people.

The article analyzes the "bottom" problem of the "Bottom of the Pyramid", which made it possible to conduct a multifaceted consideration of issues related to the functioning of markets for the poor people and identify the challenges facing the modern economy and society.

The article provides examples of effective actions in the BoP market for the development of entrepreneurship of the "bottom of the pyramid" community, namely microfinance, which is popular not only in developing countries.

The study presents the views of M. Yunus to explain the "Bottom of the Pyramid" and the new way of economic thinking, which must be used constructively to create innovative and managerial strategies.

The "Jugaad innovations" that are implemented in India, as well as in the countries of the BRICS group and 